\title{
The effect of corazonin on heartbeat reversal in pupae of the tobacco hornworm, Manduca sexta (Lepidoptera: Sphingidae)
}

\author{
KAREL SLÁMA \\ Institute of Entomology, Czech Academy of Sciences; Drnovská 507, 16100 Praha 6, Czech Republic; e-mail: slama @entu.cas.cz
}

Key words. Heartbeat reversal, anterograde heartbeat, retrograde heartbeat, insect neuropeptides, thermocardiography, optocardiography, $\left[\mathrm{Arg}^{7}\right]$-corazonin, proctolin, CCAP

\begin{abstract}
Heartbeat reversal patterns have been monitored in the body of diapausing pupae of $M$. sexta $2 \mathrm{~h}$ before and $3 \mathrm{~h}$ after the injections of $\left[\mathrm{Arg}^{7}\right]$-corazonin, using noninvasive thermographic and optocardiographic methods. Large dosages $\left(10^{-6} \mathrm{M}\right.$ final concentrations of corazonin in the body) caused almost immediate, adrenaline-like enhancement of the anterograde heartbeat. During the relatively short, acute phase of the tachycardia induced by corazonin, the systolic anterograde contractions of the heart increased in average from 10.5 to 24 pulses per min, culminating at $2.5 \mathrm{~min}$ after the injections. Duration of the acute period of tachycardia was only 7 to $20 \mathrm{~min}$, which was followed by a period of slightly elevated, residual anterograde heartbeat which persisted occasionally for 1 to $3 \mathrm{~h}$. Smaller dosages of corazonin $\left(10^{-7} \mathrm{M}\right.$ concentrations in the body) occasionally also produced a less intensive cardiotropic effect, while the more diluted samples were completely inactive. In pupae of the beetle T. molitor, injections of corazonin $\left(10^{-6} \mathrm{M}\right.$ in the body) had no effect on the rate of in vivo heartbeat at all. Pharmacological analysis of the effects of corazonin in $M$. sexta indicated that the cardiostimulating effects of corazonin did not conform with the expected action of a peptidic neurohormone. A possibility that these effects might be artifacts produced by the low molecular breakdown products of corazonin has been discussed.
\end{abstract}

\section{INTRODUCTION}

In the literature, corazonin is commonly introduced by a statement: "[Arg(7)]-corazonin was first isolated from $P$. americana as a potent cardioaccelerator (Veenstra, 1989)" (Qi-Miao et al., 2003). The cardioaccelerating properties of corazonin have been widely advertised, although experimental evidence for cardiostimulating action of corazonin is limited to just a few in vitro observations on the explanted dorsal vessels (Veenstra, 1989; Predel et al., 1994; Vilaplana et al., 1999). In addition to corazonin, however, cardiostimulating properties were also ascribed to several other groups of insect peptides (review by Holman et al., 1990; Konopińska et al., 1992; Rosiński, 1995; Nässel et al., 2002). Particularly in $P$. americana, the cardioaccelerating label has a very low significance because the in vitro increase of the heartbeat has been nonspecifically achieved by a number of various, structurally unrelated chemicals (reviews by Jones, 1977; Miller, 1979, 1997).

Research into insect neuropeptides has undergone enormous progress in the past two decades. Advanced MALDI-TOF mass spectrometric (Predel, 2001; Audsley $\&$ Weaver, 2003) and immunocytochemical techniques (Roller at al., 2003) enabled identification of neuropeptide molecules not only in the corpora cardiaca, but also within the separate neurosecretory cells of the brain. According to Schoofs et al. (2001), structural information was available in 2001 for more than 60 peptides only in locusts. Biological activity of these peptides was usually estimated by in vitro assays, based on the increased contractions of the visceral muscles. With respect to corazonin, however, new aspects in its biological activity emerged with the discovery that $\left[\mathrm{His}^{7}\right]$-corazonin could induce dark body coloration in the white, albino strain of the locust (Tanaka, 2000, 2001; Yerushalmi et al., 2002; Grach et al., 2003; Rahman et al., 2003; Shalev et al., 2003; Tanaka et al., 2003). The darkening effects on the cuticle produced by oily injections of corazonin (and some other peptides; see Yerushalmi et al., 2002), suggested the possible existence of true, in vivo, effects of the peptide. The in vivo effects of corazonin were further extended to acceleration of egg development and inhibition of food intake in locusts (Schoofs et al., 2001), reduced rate of spinning in silkworm larvae (Tanaka et al., 2002), or influence on the phase transition in locusts (Hoste et al., 2002; Breuer et al., 2003; Rahman et al., 2003).

A solid evidence for the in vivo effects of corazonin on functions of the insect dorsal vessel does not exist. According to Sláma (2003), regulation of insect heartbeat is based on the myogenic principle with inherent rhythmicity. Similarly to the case of the human heart, the rhythmicity of the insect heart is influenced by extrinsic (temperature) and intrinsic factors (direct metabolic feedback from muscular activity and intestine). Perhaps due to its myogenic nature, the insect heart is little affected by or it is resistant to a large number of neuroactive chemicals that have been tested (Miller, 1979, 1997). In the foregoing paper (Sláma \& Rosiński, 2004), we tried to determine the in vivo effects of the most investigated cardioaccelerating peptides, Proctolin and CCAP. As a model system for these investigations, we used the previously elaborated methods for monitoring the heartbeat reversal in diapausing pupae of Manduca sexta (Sláma \& Miller, 2001, 2002). In this work we take use of the 
recently developed (Sláma, 2003), touch-free, electrocardiographic methods for the prolonged monitoring of the effects of $[\operatorname{Arg}(7)]$-corazonin.

\section{MATERIAL AND METHODS}

Diapausing pupae of Manduca sexta were obtained by rearing the larvae on artificial diets at short photoperiodic illumination ( $8 \mathrm{~L}: 16 \mathrm{D}$ phase). The pupae stored at room temperature were used for the measurments from 14 days until 6 months of pupal age. In a refrigerator the pupae can be stored at $5^{\circ} \mathrm{C}$ for more than one year. Before electrocardiographic recordings, the chilled diapausing pupae were left at room temperature at least for two days. After more than 3 months at $5^{\circ} \mathrm{C}$ the chilled diapausing pupae resume adult development when brought to room temperature. In this case, the early postdiapause pupae were used only during the initial 10 days at room temperature. The injections ( $20 \mu 1$ per spec.) were made without narcosis, using a thin, 31 gauge stainless steel needle to minimize epidermal injury. $[\operatorname{Arg}(7)]$-corazonin (Sigma, Bachem) was dissolved in insect Ringer solution $\left(7.5 \mathrm{~g} \mathrm{NaCl}, 0.1 \mathrm{~g} \mathrm{KCl}, 0.2 \mathrm{~g} \mathrm{NaHCO}_{3}\right.$, $0.2 \mathrm{~g} \mathrm{CaCl}_{2}$ in 11 of $\mathrm{H}_{2} \mathrm{O}$ ) immediately before the injections. The final haemolymph concentrations of corazonin were calculated on the basis of pupal water content ( 5 to $7 \mathrm{~g}$ average pupal body mass, $70 \%$ water on $\mathrm{ml} / \mathrm{g}$ basis). In order to stop the bleeding after the injections, the wounds were immediately covered by a small drop of rapidly polymerizing cyanoacrylic glue.

The heartbeat reversal was monitored by two absolutely noninvasive, electro-cardiographic (EKG) methods. The first, a contact thermocardiographic method, used miniature thermistor sensors that were positioned and fixed outside the body, usually in the middle of the $3 \mathrm{rd}$ or $4 \mathrm{th}$ abdominal tergite. The method has been previously described by Wasserthal (1980) and Sláma (2000). Specific application of the method to pupae of $M$. sexta has been recently described by Sláma and Miller (2001) and Sláma (2003). The newly invented, pulse-light optocardiographic method (Sláma, 2003) is based on a low frequency pulse-light, which is transmitted to a patch of insect integument (usually above the abdominal pericardial region) by thin optic fibres. The reflected pulse-light, which is modulated by subepidermal movements of the dorsal vessel and other tissues, is collected by the second optic fibre through which it is transmitted to phototransistor for amplification, decoding and finally recording. The visible pulse-light is electronically filtered so that it is insensitive to the ambient light. The advantage of this technique is that the visible beam of the pulse-light can be optically concentrated on small epidermal areas $(0.3 \mathrm{~mm}$ in diameter $)$, which enables a touch-free recording of the heartbeat from a distance of some 5-7 mm.

The amounts of corazonin in the injections ( $20 \mu \mathrm{l}$ per pupa) were adjusted to give the final haemolymph concentrations of the peptide from $10^{-10} \mathrm{M}$ to $2 \times 10^{-6} \mathrm{M}$. Recordings of the heartbeat reversal were initiated at least $2 \mathrm{~h}$ before the injections and they continued without interruption for 5 to $24 \mathrm{~h}$ thereafter. Evaluations of the results were performed individually on electrocardiographic records, whose number $(n)$ has been indicated in the text or in figure captions. Major emphasis has been given to comparisons of the results obtained with corazonin injections and the sham injections ( $20 \mu \mathrm{l}$ of insect Ringer alone). The principal evaluation criteria were: a) Changes in the rate of the heartbeat before and after the injections; b) Duration of the nonspecific, postinjection induced period of the anterograde heartbeat; c) Duration of the slightly enhanced, residual heartbeat later after the injections; d) Intervals to the resumption of the regular switchovers of the heartbeat reversal (anterograde, pause, retrograde), and; d) Duration of the persisting, unidirectional anterograde pulsations. In order to facilitate description of the separate cardiological events, we have assembled in the Figures some representative parts of the authentic electrocardiographic records for illustration. Statistical evaluation of the data was made only for the large concentrations of corazonin $\left(10^{-6} \mathrm{M}\right.$ plus $2 \times 10^{-6} \mathrm{M}$ concentrations in the body; see Fig. 6 ).

\section{RESULTS}

\section{Heartbeat reversal in the normal, untreated pupae}

The diapausing or early postdiapause pupae of $M$. sexta show regular heartbeat reversal that is composed from 3 distinctly separated phases: 1 . The backward oriented or retrograde; 2 . The forward oriented or anterograde, and; 3 . The period of diastasis or cardiac rest. The common appearance of these phases on the electrocardiographic (EKG) records can be observed in Fig. 1. We can see that there are certain irregularities in the pattern, like for example, the occasional reduction or omission of the retrograde phase (upper record in Fig. 1), the slight prolongation of resting periods or the increased density of occurrence of bouts of anterograde pulsations. At a constant temperature, however, the once established pattern of the heartbeat reversal usually remains constant for many hours, days or even for several weeks.

The middle two records in Fig. 1 show the most common patterns of heartbeat reversal in pupae of $M$. sexta. We can distinctly recognize different frequencies of anterograde and retrograde pulsations. The bottom record shows the spontaneously increased, faster cardiac activity of the developing pharate adult. The rate of heartbeat progressively increases during resumption of the postdiapause development. For practial reasons, the advanced pharate adult stages were not used in our EKG recordings because the constant changes and the occurrence of extracardiac haemocoelic pulsations could seriously intervene with evaluation of the effects. Fortunately, the strong extracardiac pulsations, which usually camouflage the heartbeat pattern in other species, were completely absent in diapausing pupae of $M$. sexta.

Further advantages of the immobile, diapausing pupae of M. sexta for the EKG studies depend on: a) very constant rates of the heartbeat, b) rather constant switchovers between the anterograde and retrograde phases and, c) relatively short diastasis pauses. These features are very important for successful elimination of the nonspecific effects caused by the injection of Ringer alone (see Fig. 6 later in the text). We can find in Fig. 2 that a carefully performed injection of Ringer can eventually leave the EKG pattern unaffected. However, this ideal situation did not occur very often. In most cases, such as in the case shown in Fig. 3, injections of insect Ringer or destilled water alone induced an immediate, "out of schedule", nonspecific induction of the anterograde pulsation.

Sudden installation of the anterograde heartbeat, such as the one in Fig. 3, has not been restricted to the effects of Ringer injections. It could be also induced, for instance, by mechanical disturbances, irritation, stress, changes in temperature, as well as by extensive manipula- 

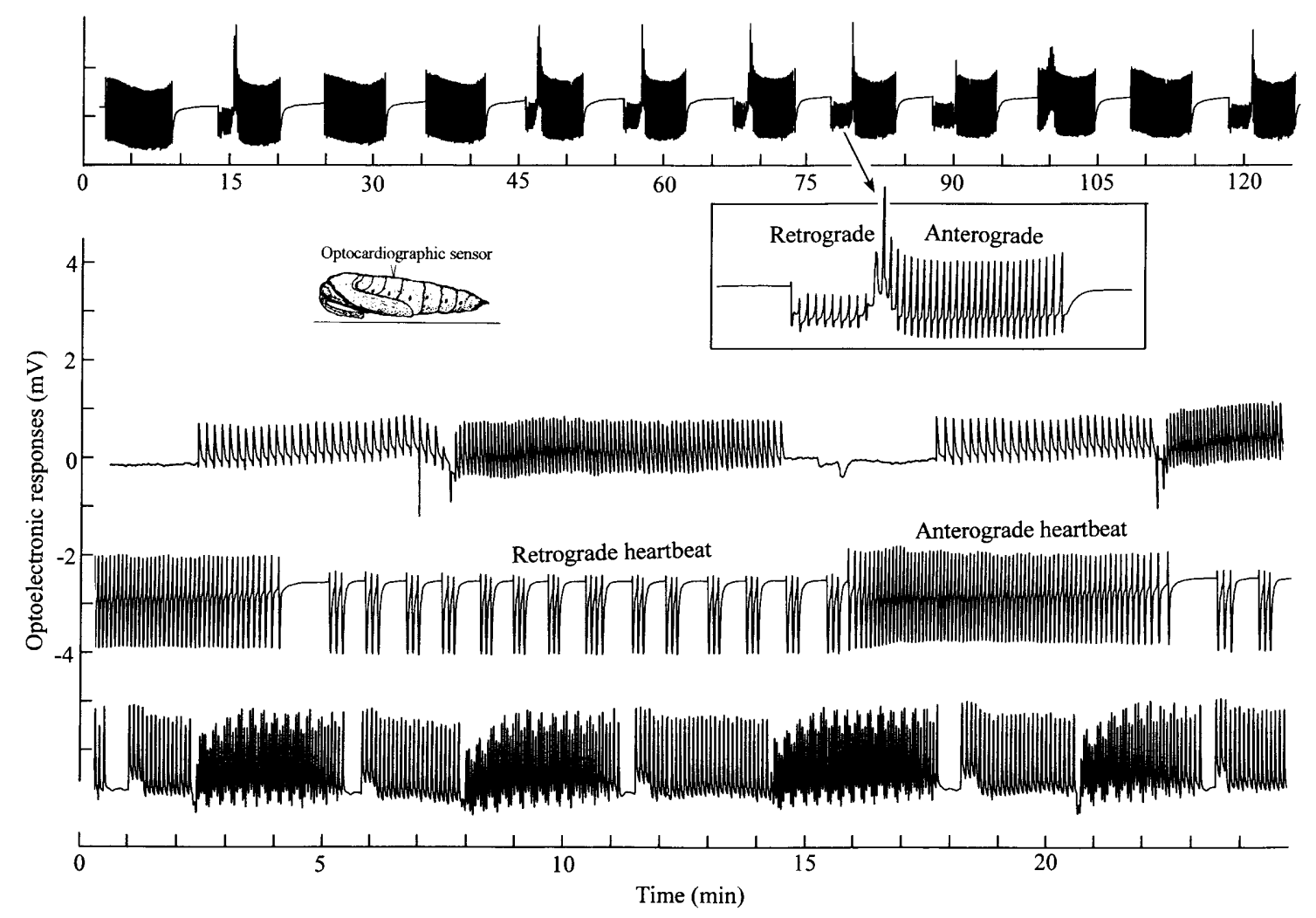

Fig. 1. Optocardiographic records of the heartbeat reversal in a diapausing pupa of $M$. sexta at room temperature. Upper record shows general pattern of the reversal with one cycle exhibited in more details in the inset (arrow). The two records in the middle show examples of the faster (anterograde) and slower (retrograde) phases that are characteristic for diapausing pupae. Bottom record shows increased cardiac activity during initial stages of the postdiapause adult development.

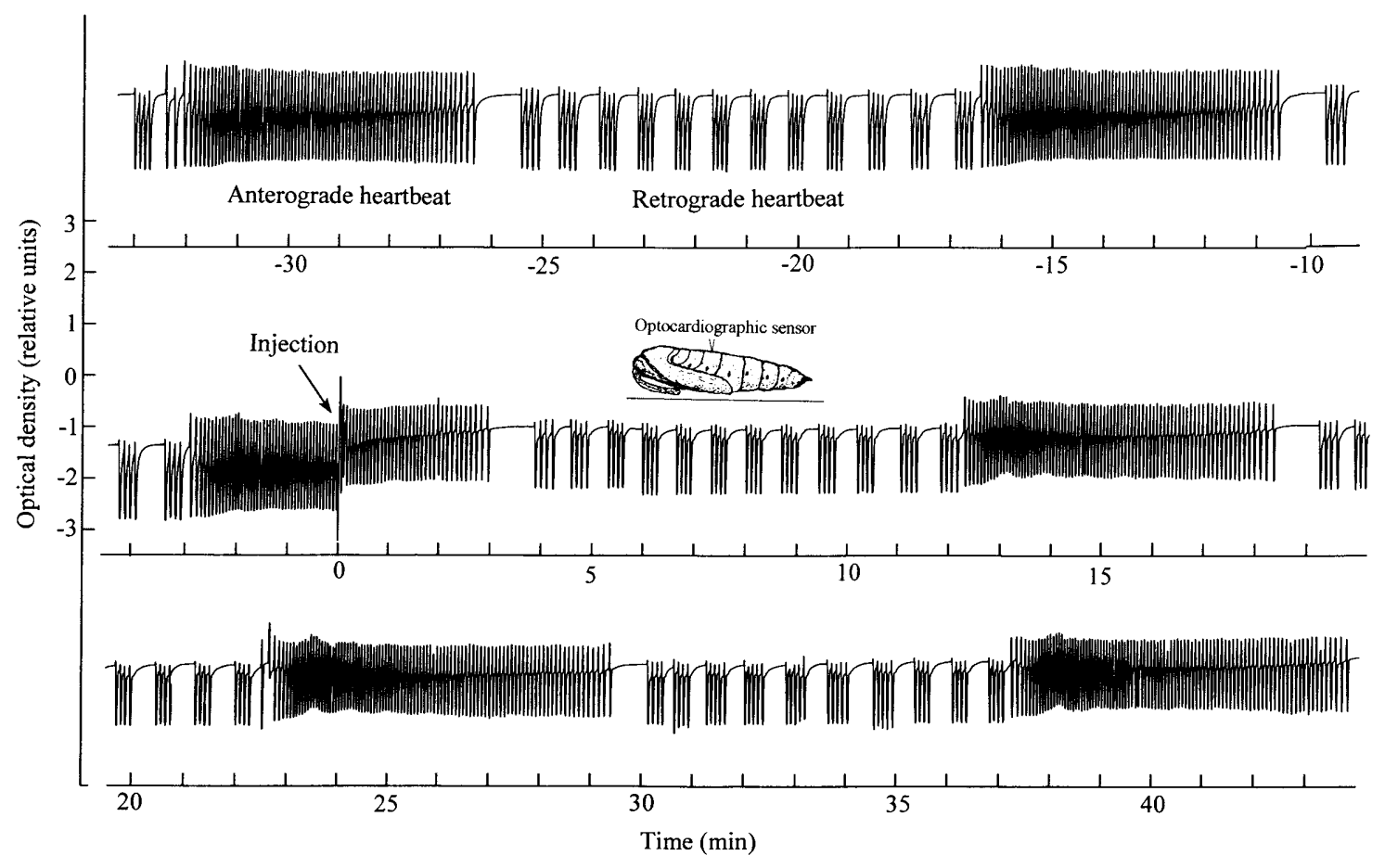

Fig. 2. Optocardiographic records of the heartbeat taken from $30 \mathrm{~min}$ before until $40 \mathrm{~min}$ after the injection of pure insect Ringer solution $(20 \mu \mathrm{l})$ into a diapausing pupa of $M$. sexta, at $24^{\circ} \mathrm{C}$. 


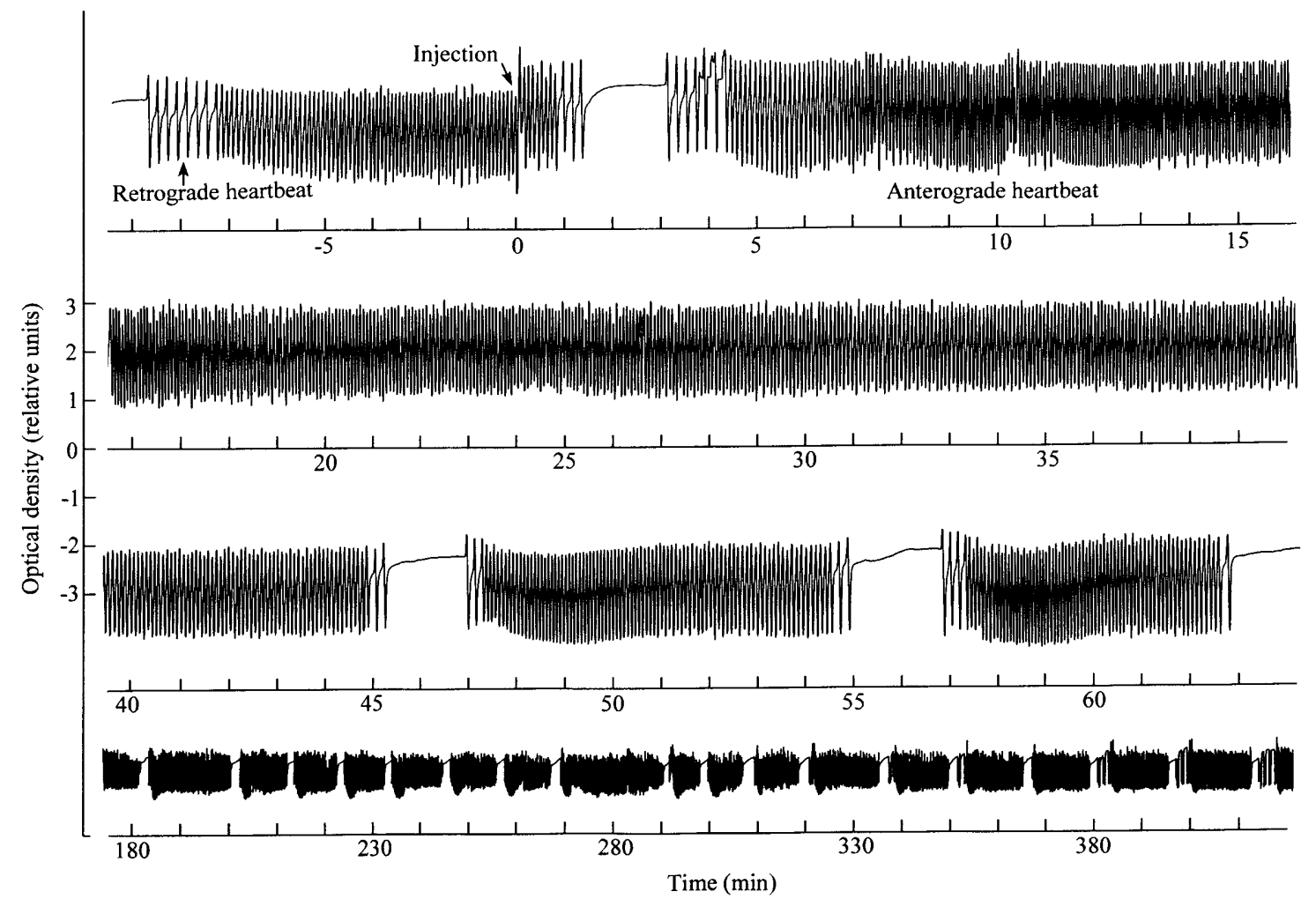

Fig. 3. Optocardiographic records which show the common, nonspecific effects of Ringer injection (20 $\mu$ l) in a diapausing pupa of M. sexta at $25^{\circ} \mathrm{C}$. The effect has been manifested by prolonged, out of schedule, installation of the forward-oriented, anterograde heartbeat.

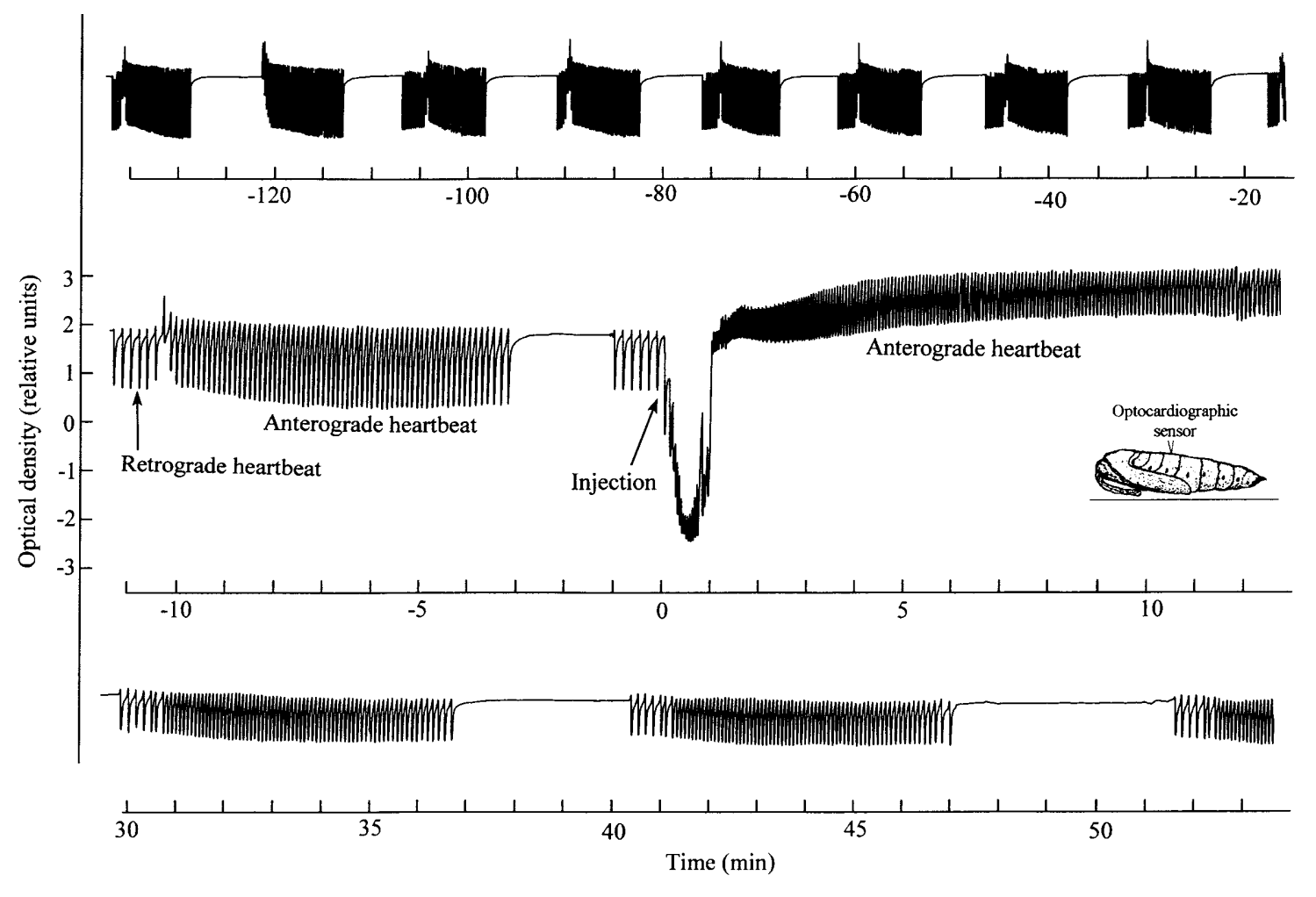

Fig. 4. The effect of corazonin (injected in $20 \mu \mathrm{l}$ of Ringer solution; $10^{-7} \mathrm{M}$ final conc. in the body) on heartbeat in the diapausing pupa of M. sexta, at room temperature. Upper record shows the regular optocardiographic pattern of the heartbeat reversal before the injection. 


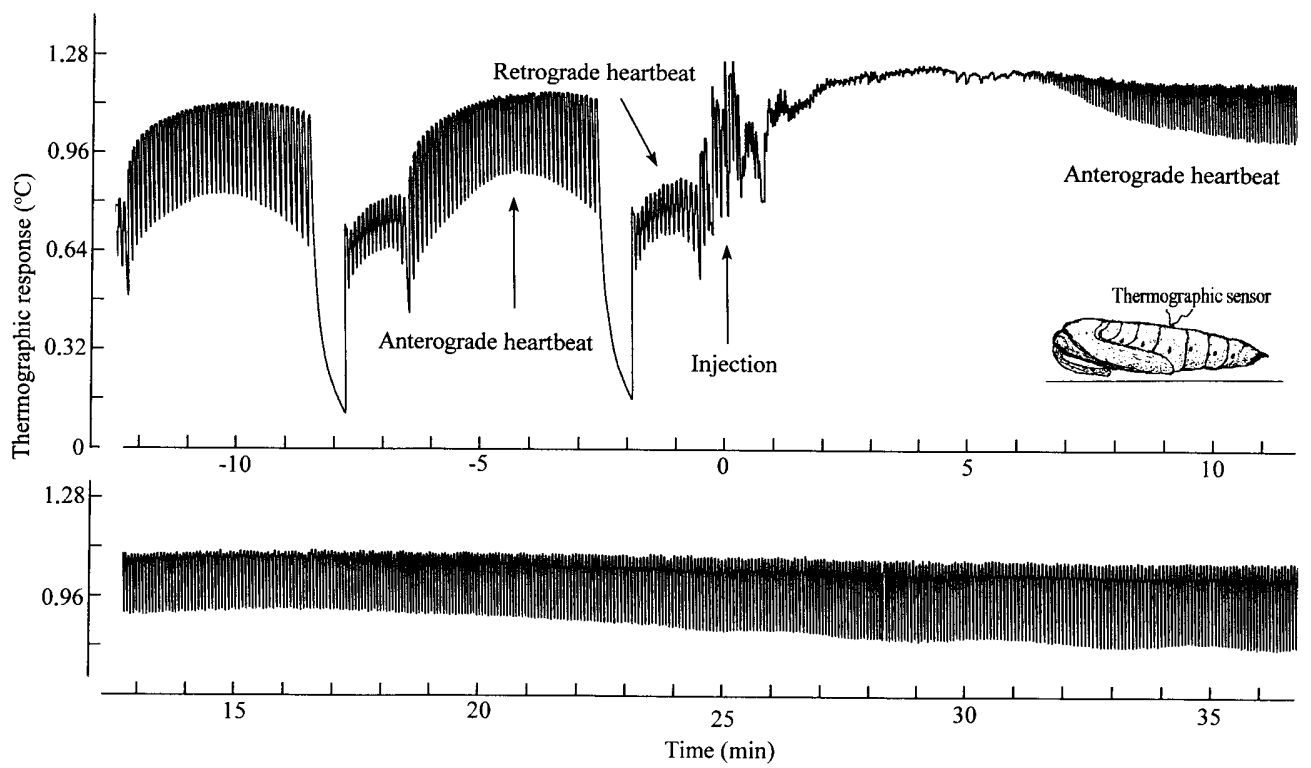

Fig. 5. The effect of corazonin $\left(10^{-6} \mathrm{M}\right.$ final conc. in the body) on the heartbeat reversal in diapausing pupa of $M$. sexta, at $25^{\circ} \mathrm{C}$. The record has been obtained by the thermographic method, which shows changes in the frequency of cardiac pulsations together with relative changes in the rate of subintegumental haemolymph flow (from zero flow during the cardiac rest to the maximum during anterograde phase).

grade pulsation towards the head seems to reflect a natural response of the pupal circulatory system to altered external conditions. Knowledge of these nonspecific effects (Fig. 3) is thus very important in discrimination of the false-positive effects caused by injections of Ringer alone. Fortunately, the nonspecific effects of Ringer injections or mechanical irritations had a very small, if any, effect on the frequency of the heartbeat.

\section{Effects of $\left[\mathrm{Arg}^{7}\right]$-corazonin on the heartbeat reversal}

Injections of corazonin $\left(2 \times 10^{-6}-10^{-7} \mathrm{M}\right.$ concentrations in the body) induced a temporary tachycardia, which was manifested by immediate rise in the heartbeat frequency. The phenomenon is illustrated by the EKG record in Fig. 4 , which shows the tachycardia response induced by a relatively small amount of corazonin $\left(10^{-7} \mathrm{M}\right.$ concentration in the body). The acute tachycardia here was rather short, only about $5 \mathrm{~min}$, the heartbeat reversal was restored rather quickly, only some $30 \mathrm{~min}$ after the injection. The $10^{-7} \mathrm{M}$ dosages of corazonin did not give us uniform results. Thus, out of the 5 recordings made, only 3 exhibited increased heartbeat, like in the case of Fig. 4, whereas the remaining 2 produced only nonspecific responses of Ringer injection alone.

The tachycardia caused by large dosages of corazonin $\left(10^{-6} \mathrm{M}\right.$ and $2 \times 10^{-6} \mathrm{M}$; sample from Sigma) was quite consistent. The increased rate of the heartbeat was more pronounced and, in some respects, it was equivalent to the effects of adrenaline in the human heart. The anterograde systolic contractions were overstimulated up to 3 -fold, the periods of acute tachycardia lasted from 7 to $20 \mathrm{~min}$ and the residual periods of slightly elevated anterograde pulsation lasted usually $35-45 \mathrm{~min}$. A practical demonstration of these effects of corazonin $\left(10^{-6} \mathrm{M}\right.$ concentration in the body) has been exemplified by an EKG record in Fig.
5. These experiments with $10^{-6} \mathrm{M}$ and $2 \times 10^{-6} \mathrm{M}$ dosages of corazonin were repeated separately 11-times (see also Fig. 6 below). The most pronounced tachycardia was induced, surprisingly, with an old sample of $\left[\mathrm{Arg}^{7}\right]$-corazonin from Sigma. Additional, short-term recordings with other materials of corazonin revealed that fresh material from Sigma was less effective, whereas fresh material obtained from Bachem was slightly effective or ineffective.

The contact thermocardiographic technique used in Fig. 5 enables direct estimation of the velocity of subintegumental flow of haemolymph under the sensor. The determined rate of the flow within the pupal pericardial sinus can be used as a criterion for the actual pumping efficiency of the heart. According to this, the EKG record in

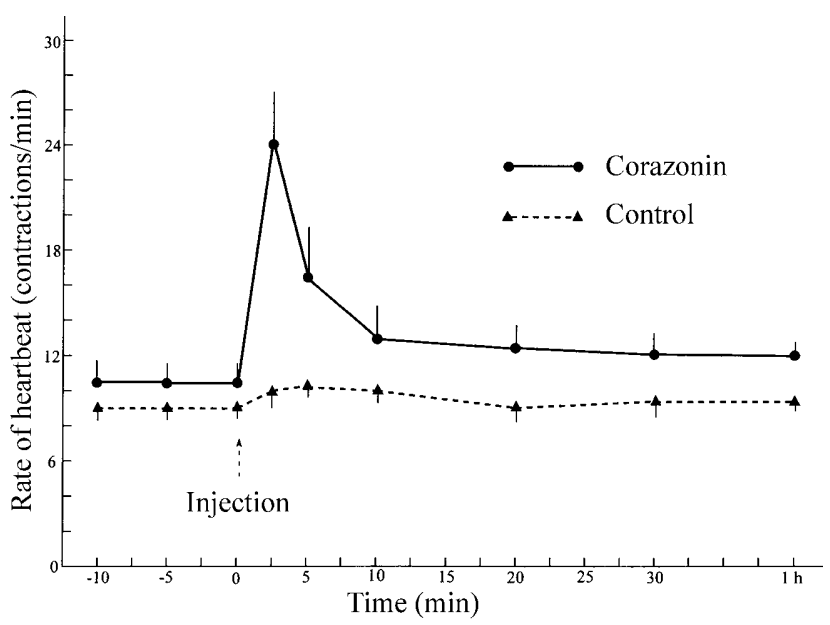

Fig. 6. Calculated average effects of corazonin (combined $10^{-6} \mathrm{M}$ and $2 \times 10^{-6} \mathrm{M}$ conc. in the body; $n=11$ ) and insect Ringer $(n=15)$ on the rate of the anterograde heartbeat during 1 hr after the injections. Vertical bars indicate SD. 


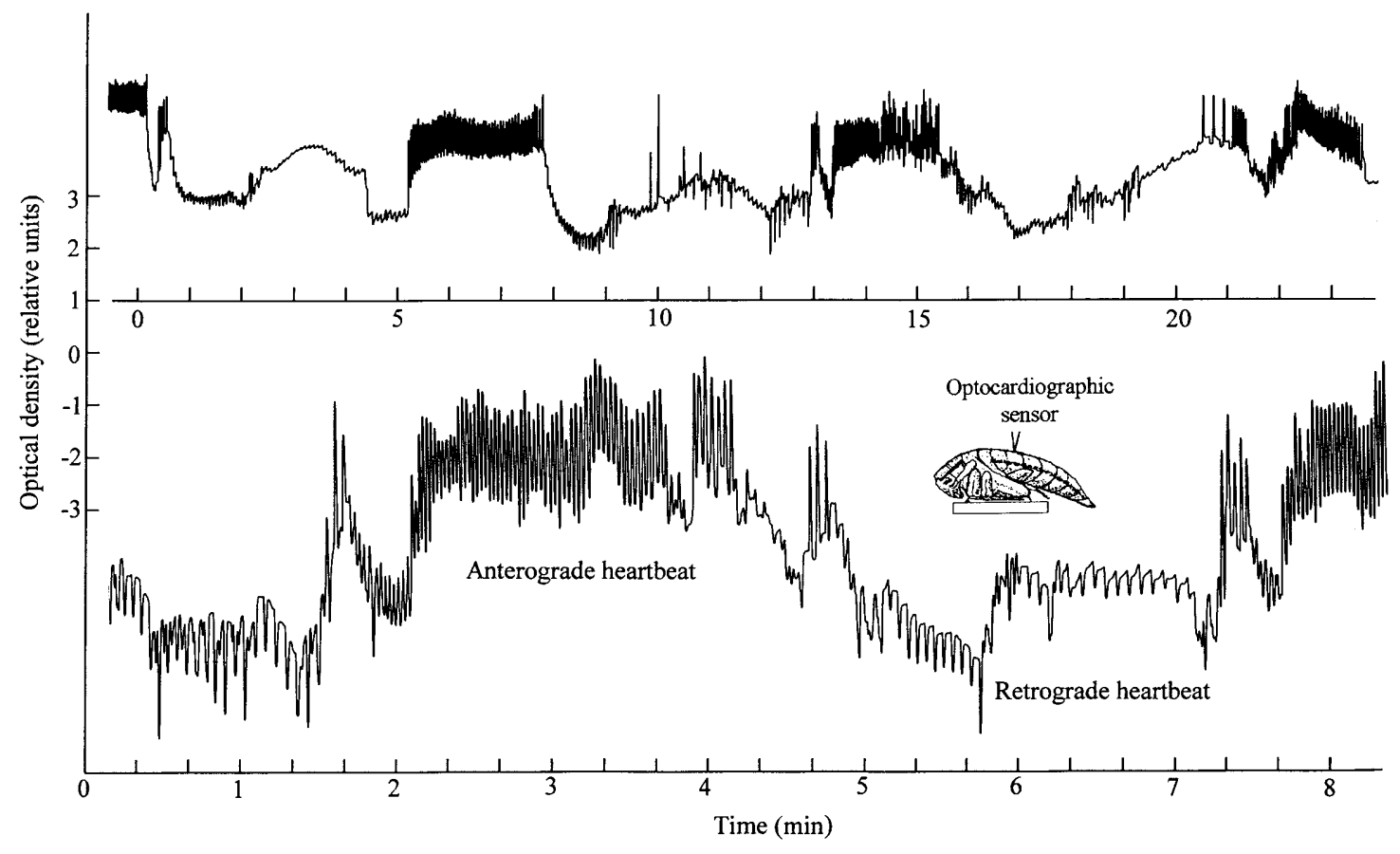

Fig. 7. Optocardiographic records showing the heartbeat reversal in a 5-day-old pupa of Tenebrio molitor L., at $25^{\circ} \mathrm{C}$. Upper record shows 4 bouts of anterograde cardiac pulsations, a more detailed lower record helps to reconcile changes in the frequency of the anterograde and retrograde heartbeats.

ciency of the heart. According to this, the EKG record in Fig. 5 indicates that a substantially enhanced flow of haemolymph occurs during the period of acute tachycardia. We can say, therefore, that the injection of corazonin $\left(10^{-6} \mathrm{M}\right)$ substantially increased the pumping efficiency of the heart.

The EKG records as shown in Fig. 4 and 5 have been also made with the more diluted samples of corazonin (SIGMA), i. e. concentrations of $10^{-7} \mathrm{M}(n=5), 10^{-8} \mathrm{M}$ $(n=4), 10^{-9} \mathrm{M}(n=8)$ and $10^{-10} \mathrm{M}(n=5)$. It was found that the ability of corazonin to respond by tachycardia responses in pupae of $M$. sexta sharply decreased below $10^{-7} \mathrm{M}$ concentration level.

The optocardiographic technique which we used gave strictly individual results; there was no "average pupa" with an "average heartbeat pattern". Nevertheless, we have calculated at least average changes in the rate of the heartbeat from $10 \mathrm{~min}$ before until $1 \mathrm{~h}$ after the injections of corazonin (combined $10^{-6} \mathrm{M}$ and $2 \times 10^{-6} \mathrm{M}$ concentrations). The results presented in Fig. 6 reveal that corazonin increased the rate of the anterograde heartbeat on average more than two-fold, with the maximum of acute tachycardia close to 2 min after the injections. In a few cases $(n=5)$, we have continuously monitored the heartbeat of pupae injected with $10^{-6} \mathrm{M}$ dosages of corazonin over a period of $20 \mathrm{~h}$. We did not find any postponed effects of corazonin, in contrast to the delayed effects of some other cardioactive peptides (Proctolin and CCAP; Sláma \& Rosiński, 2004).

\section{Effect of corazonin on the pupal heartbeat in the mealworm}

The developing pupae of the mealworm, Tenebrio molitor, show heartbeat reversal patterns that are quite similar to the patterns described in Fig. 1 to 4 for $M$. sexta. This statement can be corroborated by EKG records in Fig. 7, which show the heartbeat reversal in the pupae of T. molitor. In contrast to $M$. sexta, injections of corazonin $\left(10^{-6} \mathrm{M}\right.$ final concentrations, $\left.n=7\right)$ had no effect on the rate of the heartbeat in this coleopteran species. There was no tachycardia and the effect of corazonin injections on the heartbeat was comparable to that of the sham injected Ringer controls $(n=5)$. Moreover, there were no delayed effects of corazonin within the period of $3 \mathrm{~h}$ post-treatment.

\section{DISCUSSION}

Cardiostimulating effects of very short duration, which we have obtained with corazonin in diapausing pupae of M. sexta, show apparent similarities with the results obtained from other neuropeptides in the puparia of Drosophila (Nichols et al., 1999; Zornik et al., 1999). In both instances we can find almost immediate acceleration of the cardiac contractions within 2 or 3 min after the injections. Moreover, similar effects have been previously reported in numerous in vitro cardiological investigations including: a) corazonin (Veenstra, 1990, 1991); b) Proctolin and a number of its derivatives (Konopińska et al., 1992; Rosiński, 1995); c) neuropeptides of other families (Holman et al., 1990; Nässel et al., 2002), and; c) numerous low molecular neuroactive compounds (Jones, 1977; Miller, 1979, 1997). In addition to Drosophila, 
there were only a few examples in which the chronotropic, cardiostimulating effects of the peptides were ascertained in the living insect body. Among these examples we can include the findings in the adult moths of Manduca (Tublitz \& Truman, 1985; Tublitz, 1989; Dulcis et al., 2001), in the adult cockroaches Blatella (Vilaplana et al., 1999) and in the pupae of a coleopteran insect Zophobas (Śliwowska et al., 2002).

The in vivo, pharmacological research on insect neuropeptides represents a real challenge. The most important factor is elimination of the nonspecific effects caused by injections, altered temperature, mechanical irritation and in the adult stages we need to calculate also for the behavioural stress from restraining. Recently, we have carefully studied the nonspecific heartbeat effects caused by injections in the pupae of M. sexta (Sláma \& Rosiński, 2004). With this knowledge we have investigated possible cardiostimulating effects of Proctolin and CCAP, using similar EKG procedures as described in the present study. It was found that, in contrast to corazonin (see Figs 4 to 6), these two "cardioaccelerating" peptides had no immediate in vivo cardiostimulating activity, although they were tested at relatively large dosages of $2 \times 10^{-6} \mathrm{M}$ in the body (Sláma \& Rosiński, 2004). Injecting Ringer solution with or without the peptides had no immediate effect on the rate of the heartbeat, except for an occasionally slightly elevated (10-15\%) anterograde phase. In this respect, the present finding of adrenaline-like tachycardia by corazonin, with more than a two-fold average stimulation of the heartbeat frequency (see Figs 4-6), is quite exceptional.

The cardiological experiments with the injections of Proctolin and CCAP (Sláma and Rosiński, 2004) revealed a qualitatively new feature, which is represented by special, delayed effects of the peptides on the heartbeat. The delayed effects appeared some 2 to $5 \mathrm{~h}$ post-treatment as long periods of unidirectional, forward-oriented and faster anterograde heartbeat. This was associated with substantially enhanced haemolymph circulation (effective concentrations $10^{-9} \mathrm{M}$ in the body) lasting for several hours. It was concluded that the unusual, delayed cardiotropic effects of Proctolin and CCAP were secondary, feed-back features resulting from stimulation of some extracardiac, myotropic physiological functions.

The chemical and biochemical research of neuropeptides have hitherto advanced much ahead, leaving the endocrinological and pharmacological studies far behind. In recent years, more than 200 neuropeptide molecules have been isolated from the insect nervous system or prepared synthetically. Their physiological roles are either unknown or they have been deliberately classified as having myotropic, cardiostimulating, diuretic, antidiuretic, adipokinetic and similar other functions (reviews by Holman et al., 1990; Konopińska et al., 1992; Gäde et al., 1997; Predel et al., 2001; Nässel et al., 2002). Accordingly, the principal neurohaemal organ of insects, the corpus cardiacum, is often expected to liberate dozens of different peptidic neurohormones, which ought to be quickly destroyed or inactivated by aminopeptidase enzymes of the haemolymph (cf. Quistad et al., 1984; Predel, 2001; Schoofs et al., 2001; Nachman et al., 2002; Audsley \& Weaver, 2003; Roller et al., 2003). Professional biologists are astonished by the enormous progress in chemical synthesis and methods of peptide analysis. There is a lot of confusion, however, resulting from premature and careless assignments of biological activity of the newly isolated peptide molecules, without realization of what a peptide positively cannot do. Before the boom in isolation and synthesis of insect neuropeptides, physiologists accumulated useful data on functions of the neurosecretory cells of the brain, neurohaemal organs and other components of the retrocerebral endocrine complex (books by Pflugfelder, 1958; Novák, 1966; Sláma et al., 1974; Raabe, 1982). In order to decipher the true biological roles of neuropeptides, we need to use the old endocrinological data to show at least what the neuropeptides positively cannot do.

From endocrinological points of view, the widely advocated theories about the rapid in vivo enzymatic inactivation of the peptidic hormones may be false. During millions of years of insect evolution and natural selection, the hormone-target tissue interactions evolved accomodations resulting in enormous sensitivity. This is documented by the incredibly high biological activity of the peptidic hormones (Oxytocin, Proctolin) which can act at concentrations lower than $10^{-10} \mathrm{M}$. This range of biological activity is some 10,000 -fold below the saturation points of the hydrolytic enzymes $\left(10^{-6}-10^{-5} \mathrm{M}\right)$. At these extremely low though still effective concentrations, the peptidic hormones get resistant and practically out of the reach of the hydrolytic enzymes. Among insect hormones, the independence of hormonal activity from enzymatic hydrolysis was first demonstrated for juvenile hormone esters and the esterase enzymes (Sláma \& Jarolím, 1980). Additional experimental data questioning the impact of enzymatic degradation on in vivo hormonal activity was provided by the prolonged effects of Proctolin $\left(10^{-9} \mathrm{M}\right.$ concentrations in the body) on extracardiac haemocoelic pulsations in T. molitor (Sláma et al., 1993). We are convinced that the theory of rapid enzymatic degradation of peptidic hormones, although it is valid in laboratory assays near the saturation point of the enzymes, has no reasonable application for the hormonal activity in the living body. It is a great pity that apprehensions about rapid enzymatic inactivation has hindered the pharmacological research of peptidic hormones of insects for several decades.

The inherent rhythmicity and myogenic character of the insect heart are features similarly shared with the human heart, except that adrenaline is not the main cardiostimulating agent. The periferal endocrine glands homologous to the adrenal gland of vertebrates have not been found in insects, so far. According to Sláma (2003), there is no good physiological reason why the myogenic insect heart should be regulated by neuropeptides. It is positively regulated by feed-back mechanisms from the periphery (muscular tissue, intestine, fat body). After complete failure in attempts to show direct, in vivo cardiostimu- 
lating effects of Proctolin and CCAP (Sláma \& Rosiński, 2004), we lost confidence in the cardiostimulating properties of neuropeptides, until we found the surprisingly strong effects of tachycardia with corazonin (see Fig. 4-6). In order to explain the discrepancies in interpretation of these results, we have made additional pharmacological analysis of the effects of corazonin, with the following conclusions: 1 . The fast response to corazonin, in the range of seconds (see Fig. 4 and 5) excludes the possibility of hormonal action which should be based on a penetration of the hormone into the target myocardium cells to reach and bind with the intracellular receptor sites; 2. The adrenaline-like effect of short duration is reminiscent of cardioactive actions of numerous low molecular compounds (products of intermediary metabolism, glutamate, GABA, biogenic amines, lactate or pyruvate); 3 . The cardiostimulating effects of corazonin were limited to relatively large concentrations $\left(10^{-6} \mathrm{M}\right)$, which are close to the saturation point of the aminopeptidase enzymes, and; 4. Consequently, the effects could be nonspecifically produced by the breakdown products of corazonin, which might be present in the tested solutions already before the injections. This last argument stems from considerable inconsistencies between the results obtained with the $[\operatorname{Arg}(7)]$-corazonin of different producers. For example, an old sample from SIGMA was very active, a fresh sample from SIGMA was less active, whereas a fresh sample from BACHEM was completely inactive. This shows that factors related to purity and selfdecomposition need to be carefully respected in all future assays with peptidic materials. With this precaution in mind, we have initiated further EKG tests of all amino acid components of corazonin; the results will be published elsewhere.

The virtual absence of cardiostimulating activity of corazonin in $T$. molitor did not depend on differences in the quality of different chemical samples, because identical material that caused the tachycardia in $M$. sexta was equally ineffective in $T$. molitor. It should be mentioned in this respect that extensive histo-immunochemical assays (Tanaka, 2000, 2001; Roller et al., 2003) failed to show the presence of corazonin in tissues of the coleopteran insects.

Finally, we consider it premature to make direct comparisons between the effects of corazonin on the heartbeat in M. sexta and the effects on dark coloration of integument in locusts. The dark coloration was induced by oily injections of corazonin (water injections were ineffective) in the dosages of $1 \mathrm{nmol}$ to $50 \mathrm{nmol}$ per specimen (Tanaka, 2000; Tanaka et al., 2002; Yerushalmi et al., 2002; Hoste et al., 2002). According to our calculations, $1 \mathrm{nmol}$ of corazonin is equivalent approximately to $10^{-6} \mathrm{M}$ concentrations of corazonin per $1 \mathrm{ml}$ of the locust haemolymph. We are convinced that this is still an extremely high concentration for true biological activity of a neurohormone, although there are peptides occurring naturally in the locust haemolymph in concentrations as high as $10^{-4} \mathrm{M}$ (Hoste et al., 2002).
ACKNOWLEDGEMENTS. This work was supported by a German-Czech collaborative grant registered with the Deutsches Zentrum für Luft- und Raumfahrt as TSR-072-97 and with the Czech Ministry of Education, Youth, and Sports as CZE-00-005.

\section{REFERENCES}

Audsley N. \& Weaver R.J. 2003: A comparison of the neuropeptides from the retrocerebral complex of adult male and female Manduca sexta using MALDI-TOF mass spectrometry. Regul. Peptides 116: 127-137.

Breuer M., Hoste B. \& De Loof A. 2003: The endocrine control of phase transition: some new aspects. Physiol. Entomol. 28: $3-10$.

Dulcis D., Davis N.T. \& Hildebrand J.H. 2001: Neuronal control of heart reversal in the hawkmoth Manduca sexta. $J$. Comp. Physiol. (A) 17: 837-849.

Gäde G., Hoffmann K.H. \& Spring J.H. 1997: Hormonal regulation in insects: facts, gaps, and future directions. Physiol. Rev. 77: 963-1032.

Grach C., Wang Y., Barda Y., Gilon C. \& Pener M.P. 2003: In vivo structure-activity studies on the dark-color-inducing neurohormone of locusts. J. Peptide Res. 62: 134-142.

Holman G.M., Nachman R.J. \& Wright M.S. 1990: Insect Neuropeptides. Annu. Rev. Entomol. 35: 201-217.

Hoste B., Simpson S.J., Tanaka S., Zhu D.H., De Loof A. \& BREUER M. 2002: Effects of [His (7)]-corazonin on the phase state of isolated-reared (solitarious) desert locusts, Schistocerca gregaria. J. Insect Physiol. 48: 981-990.

Jones J.C. 1977: The Circulatory System of Insects. Ch.C. Thomas Publisher, Springfield, Illinois, $255 \mathrm{pp}$.

KonopińsKa D., Rosiński G. \& SoвÓTKA W. 1992: Insect peptide hormones, an overview of the present literature. Int. J. Peptide Prot. Res. 39: 1-11.

MilLER T.A. 1979: Nervous versus neurohormonal control of insect heartbeat. Am. Zool. 19: 77-86.

Miller T.A. 1997: Control of circulation in insects. Gener. Pharmacol. 29: 23-38.

NACHMAN R.J., IsAaC R.E. \& COAST G.M. 2002: In vivo activity of peptidase-resistant analogs of the insect kinins. In D. Konopińska (ed.): Arthropods - Chemical, Physiological and Environmental Aspects. Wydawnictwo Uniwersytetu Wrocławskiego, Wrocław, pp. 124-131.

Nässel D.R., Birse R.T., IsaAc R.T., Muren J.E. \& Winther A.M.E. 2002: Biology of tachykinin-related peptides in arthropods. In Konopińska D. (ed.): Arthropods - Chemical, Physiological and Environmental Aspects. Wydawnictwo Uniwersytetu Wrocławskiego, Wrocław, pp. 97-114.

Nichols R., Kaminski S., Walling E. \& Zornik E. 1999: Regulating the activity of a cardioacceleratory peptide. Peptides 20: $1153-1158$.

NovÁK V.J.A. 1966: Insect Hormones. Methuen \& Co., London, $478 \mathrm{pp}$.

Pflugfelder O. 1958: Entwicklungsphysiologie der Insekten. Gustav Fischer Verlag, Jena, 580 pp.

Predel R. 2001: Peptidergic neurohemal system of an insect. Mass spectrometric morphology. J. Comp. Neurol. 436: 363-375.

Predel R., Agricola H., Linde D., Wollweber L., Veenstra J. A. \& Penzlin H. 1994: The insect neuropeptide corazoninPhysiological and immunochemical studies in Blattariae. Zool. Anal. Complex Syst. 98: 35-49.

Predel R., Nachman R.J. \& Gäde G. 2001: Myostimulatory neuropeptides in cockroaches: structures, distribution, phar- 
macological activities, and mimetic analogs. J. Insect Physiol. 47: 311-324.

Qi-Miao S., Tanaka S. \& Takeda M. 2003: Immunohistochemical localization of clock proteins (DBT and PER), and $\left[\mathrm{His}^{7}\right]$ - and $\left[\mathrm{Arg}^{7}\right]$-corazonins in the cerebral ganglia of Bombyx mori: Are corazonins downstream regulators of circadian clocks? Eur. J. Entomol. 100: 283-286.

Quistad G.B., Adams M.E., Scarborough R.M., Carney R.L. \& SCHOOLEY D.A. 1984: Metabolism of proctolin, a pentapeptide neurotransmitter in insects. Life Sci. 34: 569-576.

RaAbe M. 1982: Insect Neurohormones. Plenum Press, New York, $352 \mathrm{pp}$.

Rahman M.M., Baggerman G., Begum M., De Loof A. \& BReuer M. 2003: Purification, isolation and search for possible functions of a phase-related 6080-Da peptide from the haemolymph of the desert locust, Schistocerca gregaria. Physiol. Entomol. 28: 39-45.

Roller L., Tanaka Y. \& Tanaka S. 2003: Corazonin and corazonin-like substances in the central nervous system of the Pterygote and Apterygote insects. Cell Tissue Res. 312: 393-406.

Rosiński G. 1995: Metabolic and Myotropic Neuropeptides of Insects. Zool. Series 22. A. Mickiewicz University Press, Poznań, $148 \mathrm{pp}$.

Schoofs L., Clynen E., Cerstiaens A., Baggerman G., Wei Z., Vercammen T., Nachman R., De Loof A. \& Tanaka S. 2001: Newly discovered functions for some myotropic neuropeptides in locusts. Peptides 22: 219-227.

Shalev D.E., Yerushalmi Y., Pener M.P. \& Kustanovich I. 2003: Nuclear magnetic resonance (NMR) studies of the dark-color-inducing neurohormone of locusts and corazonin. Insect Biochem. Mol. Biol. 33: 489-497.

SLÁmA K. 2000: Extracardiac versus cardiac haemocoelic pulsations in pupae of the mealworm (Tenebrio molitor L.). $J$. Insect Physiol. 46: 977-992.

SLÁmA K. 2003: Mechanical aspects of heartbeat reversal in pupae of Manduca sexta. J. Insect Physiol. 49: 645-657.

SLÁMA K. \& JAROLÍM V. 1980: Fluorometric method for the determination of juvenoid esterase activity in insects. Insect Biochem. 10: 73-80.

SlÁma K. \& Miller T.A. 2001: Physiology of heartbeat reversal in diapausing pupae of the tobacco hornworm, Manduca sexta (Lepidoptera: Sphingidae). Eur. J. Entomol. 98: 415-431.

SLÁmA K. \& Miller T.A. 2002: Heartbeat reversal in pupae of the tobacco hornworm (Manduca sexta). In D. Konopińska (ed.): Arthropods - Chemical, Physiological and Environmental Aspects. Wydawnictwo Uniwersytetu Wrocławskiego, Wrocław, pp. 27-34.

SLÁmA K. \& Rosiński G. 2004: Pharmacological effects of proctolin and CCAP on heartbeat in pupae of the tobacco hornworm, Manduca sexta. Physiol. Entomol. (in press).

Sláma K., Romañuk M. \& Šorm F. 1974: Insect Hormones and Bioanalogues. Springer, Wien, New York, 477 pp.
Sláma K., Konopińska D. \& SobotKa W. 1993: Effects of proctolin on autonomic physiological functions in insects. Eur. $J$. Entomol. 90: 23-35.

Śliwowska J., Nässel D.R., Tublitz N. \& Rosiński G. 2002: Are tachykinin-related peptides cardioacceleratory also in vivo? In D. Konopińska (ed.): Arthropods - Chemical, Physiological and Environmental Aspects. Wydawnictwo Uniwersytetu Wrocławskiego, Wrocław, pp. 71-78.

TANAKA S. 2000: The role of [His(7)]-corazonin in the control of body-color polymorphism in the migratory locust, Locusta migratoria (Orthoptera: Acrididae). J. Insect Physiol. 46: 1169-1176.

TANAKA S. 2001: Endocrine mechanisms controlling body-color polymorphism in locusts. Arch. Insect Biochem. Physiol. 47: 139-149.

Tanaka Y., Hua Y.J., Roller L. \& TanaKa S. 2002: Corazonin reduces the spinning rate in the silkworm, Bombyx mori. $J$. Insect Physiol. 48: 707-714.

Tanaka Y., Ishibashi J. \& Tanaka S. 2003: Comparison of structure-activity relations of corazonin using two different bioassay systems. Peptides 24: 837-844.

TuBLitz N. 1989: Insect cardioactive peptides: Neurohormonal regulation of cardiac activity by two cardioacceleratory peptides during flight in the tobacco hawkmoth, Manduca sexta. J. Exp. Biol. 142: 31-48.

Tublitz N.J. \& TRUMAN J.W. 1985: Insect cardioactive peptides. II. Neurohormonal control of heart activity by two cardioacceleratory peptides in the tobacco hawkmoth, Manduca sexta. J. Exp. Biol. 114, 381-395.

VEENSTRA J.A. 1989: Isolation and structure of corazonin, a cardioactive peptide from American cockroach. FEBS Lett. 250: 231-234.

VeEnSTRA J.A. 1990: Isolation and structure of three neuropeptides from the corpora cardiaca of the American cockroach. In Borkovec A.B. \& Masler E.P. (eds): Insect Neurochemistry and Neurophysiology 1989. Humana Press, Clifton, NJ, pp. 223-226.

Veenstra J.A. 1991: Presence of corazonin in three insect species and isolation and identification of $\left[\mathrm{His}^{7}\right]$-corazonin from Schistocerca americana. Peptides 12: 1285-1289.

Vilaplana L., Maestro J.L., Piulachs M.D. \& Belles X. 1999: Modulation of cardiac rhythm by allatostatins in the cockroach Blatella germanica (L.) (Dictyoptera, Blattidae). $J$. Insect Physiol. 45: 1057-1064.

Yerushalmi Y., Bhargava K., Gilon C. \& Pener M.P. 2002: Structure-activity relations of the dark-colour-inducing neurohormone of locusts. Insect Biochem. Mol. Biol. 32: 907-917.

Wasserthal L.T. 1980: Oscillating haemolymph "circulation" in the butterfly Papilio machaon L. revealed by contact thermography and photocell measurements. J. Comp. Physiol. 139: 145-163.

Zornik E., Paisley K. \& Nichols R. 1999: Neural transmitters and a peptide modulate Drosophila heart rate. Peptides 20: $45-51$.

Received April 13, 2004; revised June 25, 2004; accepted June 25, 2004 